\title{
Regulating Pacific Seasonal Labour in Australia
}

\author{
Therese MacDermott and Brian Opeskin
}

\section{Introduction}

fter many years of resisting a temporary worker scheme involving its
Pacific neighbours, in August 2008 the Australian government
announced that a pilot seasonal worker scheme would be introduced in Australia. Four Pacific Island countries-Kiribati, Papua New Guinea, Tonga and Vanuatu - have been selected for the pilot scheme, and workers from these countries will be allowed to undertake low-skilled work in the Australian horticulture industry in nominated regional locations. A labour mobility scheme of this nature is a significant departure from Australia's previous adherence to a policy of permanent settlement and skilled migration. Many factors have contributed to this policy realignment, including lobbying from the farming sector, ${ }^{1}$ persistent pressure from Pacific Island countries, a reinvigorated engagement with the Asia Pacific region following a change of Australian government in late 2007 and New Zealand's perceived early successes with a comparable seasonal work scheme.

Labour mobility schemes are often promoted as having the potential to achieve multiple goals. For the sending country, they are presented as part of a development perspective which focuses on the potential to provide developing communities with employment opportunities, the benefits of regular remittances and the chance for skills enhancement. For the receiving country, labour mobility schemes are seen as meeting labour shortages in developed economies, especially in labour intensive seasonal industries where employers may find that a reliable workforce is lacking. The adoption of a seasonal labour scheme has been described by Australia's Parliamentary Secretary for Pacific Island Affairs as "part of a comprehensive new approach to deepening our bilateral partnerships and strengthening our overall engagement with the region"; ${ }^{2}$ as adding symbolic value as a gesture of goodwill towards Australia's Pacific neighbours; ${ }^{3}$ as having the potential to

\footnotetext{
1 National Farmers' Federation, 2008 Labour Shortage Action Plan (Canberra: National Farmers' Federation, 2008).

2 D. Kerr, "Pacific Seasonal Worker Pilot Scheme," speech delivered at the Memorandum of Understanding Signing Ceremony, Canberra, 24 November 2008.

World Bank, Pacific Islands at Home and Away: Expanding Job Opportunities for Pacific Islanders through Labor Mobility (Washington DC: World Bank, 2006), p. 134.
} 
contribute to stability and security in the region; ${ }^{4}$ and as a powerful catalyst for regional integration. ${ }^{5}$ Whether these goals can be realized will be tested over time. The pilot program spans approximately three years from November 2008 to June 2012, with a planned review after 18 months and 30 months of operation.

The potential for exploitation of workers engaged under temporary or guest worker schemes has been a concern internationally for many decades. ${ }^{6}$ Proponents of seasonal worker schemes have acknowledged that they often involve compromises in which individual rights of workers are traded away for greater access to employment opportunities in developed countries. ${ }^{7}$ Ultimately, it is a question of how best to secure the fundamental rights of seasonal workers while still meeting the needs of receiving countries.

In the case of Australia's pilot scheme, local concerns have many dimensions and this has led to a dense web of government regulation designed to ensure that the scheme does not fail politically. First, there is a foreign relations dimension, which is directed towards improving Australia's bilateral relations with its Pacific neighbours as part of the government's new engagement with the Asia Pacific region. Second, there is a trade union dimension, which is directed towards accommodating the interests of labour organizations with which the Labor government has longstanding political ties. Although Australian trade unions have recently softened their approach to a seasonal worker scheme, they are still outspoken in their views that the scheme must not involve a lowering of workplace standards or any loss of jobs for Australian workers. Third, there is the need to meet public expectations by avoiding a repetition both of Australia's nineteenth-century history of exploitation of Pacific labour and of the much more recent history of abuse and discrimination against temporary skilled migrants under what is commonly referred to as the " 457 visa scheme."

The first part of this article examines the historical context of labour mobility in the Pacific, the framework of Australia's seasonal worker pilot scheme, and the key features of its New Zealand progenitor, the Recognized Seasonal Employer program. The second part provides an overview of Australia's recent experience of temporary skilled migration from the Asia Pacific region, which highlights the potential problems of exploitation and discrimination that can arise under temporary work programs and provides a cautionary tale for Australia's pilot seasonal work scheme. The third part of the article examines the web of protective regulation that has been introduced

\footnotetext{
4 Australian Senate, Perspectives on the Future of the Harvest Labour Force (Canberra: Standing Committee on Employment, Workplace Relations and Education, 2006), p. 48.

AusAID, Pacific Economic Survey 09: Engaging with the World (Canberra: Australian Agency for International Development, 2009), p. 82.

$6 \quad$ M. Ruhs, Temporary Foreign Worker Programs: Policies, Adverse Consequences, and the Need to Make Them Work (Geneva: International Labour Office), 2003.

7 World Bank, Pacific Islands at Home and Away, p.136.
} 
specifically to address seasonal migration from the Pacific. This includes intergovernmental agreements, close departmental oversight, use of local advisory bodies and a government insistence that Pacific labour is contracted through labour hire companies rather than directly by growers. The fourth part considers how the general regulatory framework of Australian industrial law and policy applies to seasonal workers and supplements the special arrangements. Critical factors are the comprehensive coverage of safety and equality issues, trade union involvement and the mechanisms available for resolving workplace disputes between Pacific workers and their employers, and between Pacific workers and their fellow workers. The article concludes by highlighting how these regulatory arrangements may affect the long-term viability of the scheme and its capacity to move beyond a pilot program to provide sustained opportunities for Pacific workers and local growers alike.

\section{Pacific labour mobility}

Movement of labour within the Pacific region is not a new phenomenon. The need for large pools of labour for plantations and mines during the colonial era led to significant migration of workers within the region, particularly to the French and British territories of New Caledonia and Fiji. ${ }^{8}$ Countries such as Nauru have historically drawn from their Pacific neighbours (especially Kiribati, Tuvalu, Vanuatu and Solomon Islands) to provide labour for the mining sector. Australia itself has a sorry history of forced removal of Pacific Islanders to work on farms in Queensland and New South Wales dating back to the nineteenth century, a practice that became known as "blackbirding."

However, since the early twentieth century the Melanesian countries of Papua New Guinea, Solomon Islands and Vanuatu have had little access to labour opportunities on the Pacific Rim. By contrast, many Micronesian and Polynesian peoples have had opportunities to access jobs in developed economies in New Zealand, the United States and France because of special citizenship rights or preferential visa access for residents of current or former Pacific territories. ${ }^{10}$ Other ad hoc arrangements have also evolved over time, such as the practice of workers from Fiji, Kiribati and Tuvalu crewing on international shipping vessels of particular flag states. ${ }^{11}$

\footnotetext{
V. Naidu, "Modernisation and Development in the South Pacific," in A. Jowitt and T. Newton Cain, ed., Passage of Change: Law, Society and Governance in the Pacific (Canberra: Pandanus Books, 2003), pp. 16-17.

9 E. Docker, The Blackbirders: The Recruiting of South Seas Labour for Queensland 1863-1907 (Sydney: Angus and Robertson, 1970); J. MacClancy, To Kill a Bird with Two Stones: A Short History of Vanuatu (Port Vila: Vanuatu Cultural Centre, 2002), pp. 58-68.

10 B. Opeskin and T. MacDermott, "Resources, Population and Migration in the Pacific: Connecting Islands and Rim," Asia Pacific Viewpoint, vol. 50, no. 3 (2009), pp. 363-367.

11 H. Ware, "Demography, Migration and Conflict in the Pacific," Journal of Peace Research, vol. 42 (2005), pp.435-454; J. Dennis, Pacific Island Seafarers: A Study of the Economic and Social Implications of Seafaring on Dependents. Suva: Secretariat of the Pacific Community, 2003, pp. 12-13.
} 
Over a sustained period, the Australian government resisted pressure to give preferential treatment to Pacific Islanders through a temporary work scheme, despite numerous recommendations that favoured trying out such a scheme. ${ }^{12}$ Part of this resistance was based on a claim that Australia's immigration policy was strictly non-discriminatory with respect to country of origin and that immigration was "selective, skilled and tightly managed."13 The exception was Australia's neighbourly relationship with New Zealand, whose citizens enjoy special rights to enter and work in Australia under the 1973 Trans-Tasman Travel Arrangements. While Australia's immigration policy may be non-discriminatory in terms of country of origin (expect for New Zealanders and those Pacific Islanders who are entitled to New Zealand citizenship), there is obviously discrimination on other grounds, such as age, family relations, health status, language ability, educational level and jobs skills. ${ }^{14}$

Australia's historic preference for skilled migration has had a number of consequences. First, very few workers from Melanesia gain access to Australia under skilled migration schemes. ${ }^{15}$ Second, the opportunities that do exist for skilled migration, whether from Melanesia or elsewhere, have contributed to a Pacific "brain drain." ${ }^{16}$ The reality is that those who most need jobs are unskilled workers with few opportunities for paid employment in the Pacific region and even fewer prospects of migrating to Pacific Rim countries. As Nic Maclellan has observed, many Pacific Island countries are "characterised by an oversupply of unskilled workers and an undersupply of skilled workers." ${ }^{17}$ Third, the emphasis on skilled migration has not supplied the reliable and regular workforce needed for seasonal work in the Australian horticulture industry because the deficiencies in labour supply do not relate primarily to skilled or semi-skilled workers but to entry level positions of an unskilled or relatively low-skilled nature. As a result, the industry has had to rely on a mixture of documented and undocumented workers, backpackers on working holiday visas, and "grey nomads" (i.e., peripatetic retirees). Fourth, although Australia's stated preference has been for permanent migration, recently there has been a large expansion of temporary long-stay business visas, known

12 R. Jackson, Report of the Committee to Review the Australian Overseas Aid Program (Canberra AGPS, 1984); Senate Standing Committee on Foreign Affairs Defence and Trade, Australia's Relations with Papua New Guinea and the Island States of the Southwest Pacific (Canberra: Parliament of Australia, 2003); AusAID, Core Group Recommendations Report for a White Paper on Australia's Aid Program (Canberra: Australian Agency for International Development, 2005), p. 69.

13 A. Millbank, A Seasonal Guest-Worker Program for Australia? (Canberra: Australian Parliamentary Library, 2006), p. 2.

14 R. Appleyard and C. Stahl, South Pacific Migration: New Zealand Experience and Implications for Australia (Canberra: AusAID, 1995).

15 R. Bedford, E. Ho, V. Krishnan and B. Hong, "The Neighbourhood Effect: The Pacific in Aotearoa and Australia," Asian and Pacific Migration Journal, vol. 16, no. 2 (2007), p. 265.

16 See, e.g., P. Brown and J. Connell, "The Migration of Doctors and Nurses from South Pacific Island Nations,” Social Science E Medicine, vol. 58 (2004), pp.2193-2210.

17 N. Maclellan, Workers for All Seasons? Issues from New Zealand's Recognised Seasonal Employer (RSE) Program (Melbourne: Swinburne Institute for Social Research, 2008), p. 11. 
as "457 visas," which do not facilitate permanent migration. Presumably, considerations other than skill and permanency could inform migration policy in this area, including outward-looking factors such as enhancing development assistance and promoting regional stability. ${ }^{18}$

In contrast to Australia, New Zealand has had an active engagement over many decades with Pacific workers from its current and former territories. New Zealand has taken an approach that acknowledges its "special relationship" with Pacific Island countries, especially in Polynesia. In recognition of these strong historical ties, residents of Cook Islands, Niue and Tokelau are New Zealand citizens and are therefore able to pursue employment opportunities in New Zealand.$^{19}$ Since the 1960s there has been a special Samoan quota system that currently allows up to 1,100 Samoan citizens to be granted residence in New Zealand each year. ${ }^{20}$ In 2002 New Zealand added a further dimension to these arrangements with a new visa class-the Pacific Access Category-which provides additional migration opportunities through random balloting for residents of other Pacific Island countries with which New Zealand has close cultural or historical ties. ${ }^{21}$ Some of these arrangements have consequences for Australia because Pacific Islanders who have New Zealand citizenship can enter and work in Australia under the Trans-Tasman Travel Arrangements. New Zealand has also had a number of programs, dating back to the 1970s, to grant permits to low-skilled workers to pursue temporary employment in the agriculture and forestry industries. Much of this work was undertaken by Samoans, Tongans and Fijians. New Zealand's new seasonal worker scheme, announced at the Pacific Islands Forum Secretariat meeting in Fiji in October 2006, is designed as a single policy framework, and other programs such as the work permit schemes are to be phased out over time. ${ }^{22}$

\section{Australia's Pacific Seasonal Worker Pilot Scheme}

The Pacific Seasonal Worker Pilot Scheme makes provision for up to 2,500 Pacific Islanders to work in the Australian horticulture industry over a threeyear period for up to seven months in a year. Since the scheme was announced in August 2008, bilateral memoranda of understanding (MOUs) have been signed between Australia and Vanuatu, Tonga and Kiribati, and an agreement with Papua New Guinea has been concluded and is expected to be signed in the near future. The scheme targets up to 800 workers from Vanuatu, 800

18 Appleyard and Stahl, South Pacific Migration, pp. 9-10.

19 Citizenship Act 1977 (NZ) s.6, Bill of Rights Act 1990 (NZ) s.18.

20 This scheme has been attributed to "the spirit of close friendship embodied in the 1962 Treaty of Friendship between New Zealand and Samoa," New Zealand Department of Labour, Migration Trends 2006/07 (Wellington: Department of Labour, 2008), p. 86.

21 The annual quota of 400 places is currently allocated between Tonga (250), Tuvalu (75), and Kiribati (75). The participation of Fiji Islands was suspended following the 2006 coup.

22 Bedford et al, "The Neighbourhood Effect," pp. 260-261. 
from Tonga, 250 from Kiribati, and 650 from Papua New Guinea. The first phase of the pilot was to recruit up to 100 seasonal workers, but in fact only 56 arrived in Australia to work-50 Tongans and 6 ni-Vanuatu. The second phase is to recruit the remaining 2,444 workers.

Two regional areas were initially selected for the pilot scheme: the Swan Hill-Robinvale region in Victoria and the Griffith region in New South Wales. Other regions are now being considered where there is a demonstrated unmet demand for labour and a sufficiently long harvest season to warrant participation in the scheme.

The scheme is premised on the existence of unmet labour demand in the Australian horticulture industry. Approval for growers to participate in the scheme depends on their ability to show they have tested the local labour market and taken reasonable steps to recruit Australian nationals. Oversight of the scheme is vested in local advisory bodies established for each geographical region. Horticultural growers in the designated regions apply to their local advisory body for access to seasonal workers, indicating the number of workers required, the period of available work and the desired skills and attributes of workers. Approval for growers to participate in the scheme is dependent on their willingness to participate in other labour market programs to assist in the placement of disadvantaged workers, including income support recipients, Indigenous Australians and humanitarian job seekers. ${ }^{23}$ Once a grower has obtained approval, he does not contract directly with Pacific workers but instead negotiates with the labour hire company that has been appointed to manage the recruitment and placement of workers for the region. A significant feature of the scheme is that the labour hire company is the employer of the workers, a factor discussed further below. To be selected for the scheme, labour hire companies must demonstrate a solid history of workplace compliance and established human resources polices and procedures.

\section{The New Zealand model}

New Zealand's Recognised Seasonal Employer scheme (the RSE scheme) provides for up to 8,000 workers annually to be engaged planting, maintaining, harvesting and packing crops in the horticulture and viticulture industries for up to seven months in a year. The local labour market must be tested before turning to recruitment from the Pacific region and South East Asia. In order to achieve recognized status under the scheme, an employer is subject to a vetting process that looks at past workplace practices, evidence of written employment policies and procedures and the facilities available for the workers. Once recognized, an employer can seek an

23 P. Mares, "Objections to Pacific Seasonal Work Programs in Rural Australia," Public Policy, vol. 2, no. 1 (2007), p. 73. 
"agreement to recruit" overseas workers, setting out the number of workers required, their roles and the duration of employment. The scheme initially involved a number of trial countries (Kiribati, Samoa, Tonga, Tuvalu and Vanuatu), with a view to recruiting labour from all Pacific Islands Forum countries if the scheme were successful. ${ }^{24}$ To date, the largest number of workers has come from Vanuatu. Under the RSE scheme, an employer is obliged to meet half the travel costs of the Pacific workers, guarantee a minimum number of hours of work, and arrange various aspects of pastoral care, including accommodation, transport, recreation and the opportunity for religious observance. A visa to undertake this work is dependent on having a job offer from an RSE registered employer and the worker passing various health and character tests.

The New Zealand scheme has been in operation since April 2007, offering Australia the opportunity to review its neighbour's experience and fine tune its own scheme. The New Zealand Department of Labour has described the scheme as "on track to achieve its aims," while acknowledging that issues have arisen in its early stages regarding pay and deductions, cost and quality of accommodation, hours of work and productivity, and induction and training. ${ }^{25}$ An independent study of the operation of the New Zealand scheme, funded by the Australian Research Council, identified a number of areas of disputation, including housing, consistency of available work, payment rates and deductions. The study suggested that seasonal work programs "require investment and interventions outside the straight employer/employee relationship" and found there was a need for greater engagement with trade unions, the community sector and Pacific communities, particularly regarding pastoral care and support services for workers and their home communities. ${ }^{26}$ In June 2009 the New Zealand Government foreshadowed changes to the system of pay deductions, which have generated some controversy. Research on the selection of workers from Tonga for the RSE scheme indicates that the program is targeting comparatively poor and unskilled workers with restricted incomes and schooling, thereby creating opportunities that would not otherwise exist for these workers. ${ }^{27}$

\section{Temporary skilled migrants: A cautionary tale}

Australia has another temporary migration program relevant to the Asia Pacific region, which provides a cautionary tale about the potential for

24 The Pacific Islands Forum has 16 full members, including Australia and New Zealand.

25 New Zealand Department of Labour, Recognised Seasonal Employer (RSE) Policy: Stakeholder Update (Wellington: Department of Labour, 2008).

26 Maclellan, Workers for All Seasons, pp. 6, 31.

27 J. Gibson, D. McKenzie, and H. Rohorua, "How Pro-Poor Is the Selection of Seasonal Migrant Workers from Tonga under New Zealand's Recognised Seasonal Employer Program?," Pacific Economic Bulletin, vol. 23, no. 3 (2008), pp.187-204. 
exploitation and discrimination in temporary work schemes. In 1996 a new class of visa, commonly known as the " 457 visa" was introduced to allow for employer-sponsored migration of skilled workers to Australia for up to four years. Like the Pacific seasonal worker scheme, its object was to meet temporary labour shortages, which became more acute as the Australian resource boom took off after 2002. The program expanded from an annual intake of around 16,500 workers in 1997-1998 to nearly 60,000 workers in 2007-2008, plus their dependants. The cumulative effect of the annual intake has been significant: by 31 December 2008 there were 132,023 such workers in Australia. Of the 40 percent from the Asia Pacific region, the most populous national groups were Indians $(13,167)$, Filipinos $(11,587)$ and mainland Chinese $(8,902)$. The number of skilled migrants from the Pacific is small relative to other national groups (931 Papua New Guineans, 917 Fijians and 175 "others") but still significant relative to the 2,500 potential Pacific workers under the seasonal worker scheme. ${ }^{28}$

The increase in 457 visa migration, and its gradual expansion from skilled to semi-skilled workers in trades, mining and manufacturing, has been accompanied by an increasing number of reports of poor working conditions, workplace discrimination and exploitation. ${ }^{29}$ The Australian Manufacturing Workers' Union (AMWU) campaigned actively against the program, describing it as "a new form of indentured servitude" and decrying that "temporary visas are being misused by...unscrupulous employers to provide a source of cheap, bonded labour." ${ }^{30}$

Sustained criticisms of the 457 visa program led to a number of internal and external reviews. ${ }^{31}$ In one of these reviews, Commissioner Deegan documented allegations of mistreatment of migrant workers under the scheme, including not being paid overtime, working longer hours than nonvisa employees, limited access to sick leave, dismissal for taking sick leave, dismissal because of pregnancy, dismissal for taking leave to care for a sick spouse or child, overcharges on rent or other expenses organized by the employer and sexual harassment in the workplace. ${ }^{32}$ In addition, several employers of 457 workers have been prosecuted successfully under industrial laws for failing to provide workers with required information about the terms

28 Australian Government, Immigration Update July to December 2008 (Canberra: Department of Immigration and Citizenship, 2009), pp. 47-48.

${ }_{29}$ M. Bissett and I. Landau, "Australia's 457 Visa Scheme and the Rights of Migrant Workers," Alternative Law Journal, vol. 33, no. 3 (2008), pp.142-146.

30 Australian Manufacturing Workers' Union, Temporary Skilled Migration: A New Form of Indentured Servitude (Melbourne: AMWU, 2006).

31 Australian Government, Discussion Paper: Business (Long Stay) Subclass 457 and Related Temporary Visa Reforms (Canberra: Department of Immigration and Citizenship, 2008); Visa Subclass 457 External Reference Group, Final Report to the Minister for Immigration and Citizenship (Canberra: Department of Immigration and Citizenship, 2008); B. Deegan, Visa Subclass 457 Integrity Review: Final Report (Canberra: Department of Immigration and Citizenship, 2008).

32 Deegan, Visa Subclass 457 Integrity Review, p. 6. 
of their employment agreement, for pressuring workers to sign an employment agreement and for breaching occupational health and safety laws. ${ }^{33}$

The problems that have been exposed in the 457 visa program are a telling reminder of the vulnerability of foreign workers in temporary employment schemes. Proposed government reforms have now sought to address some of the most pressing concerns by increasing wages for foreign workers so that local wages and conditions are not undermined, increasing the minimum language requirement, requiring employers to demonstrate a record of non-discriminatory employment practices and enhancing formal monitoring and compliance. The Pacific seasonal worker pilot scheme stands to gain significantly from the experience of the 457 visa program, and we now turn to consider how Pacific workers are protected under the pilot scheme.

\section{Special regulatory protections for seasonal workers}

The fairness of temporary labour schemes is often a highly contested issue. For example, the Canadian Seasonal Agricultural Workers Program, which has been operating for the past four decades and draws agriculture workers from the Caribbean and Mexico, has been described by some as a "reasonable model" that provides "useful lessons for Australia," ${ }^{34}$ while others have called it Canada's "shameful little secret." ${ }^{35}$ Central to any assessment of the Australian scheme is the extent to which measures have been set in place to minimize the prospect of exploitation of Pacific workers.

In its 2006 report on enhancing labour mobility in the Pacific, the World Bank identified a broad range of protections that are essential to temporary work schemes. ${ }^{36}$ Some of these are based on broad principles of equality and non-discrimination, such as entitlements to pay equality with local workers; others recognize fundamental labour standards such as freedom of association. A temporary labour scheme can offer significant protections for workers if parameters are set to guarantee minimum length of stay, minimum hours of work, sharing of costs and reasonable deductions. Dispute resolution mechanisms that make provision for the fair handling complaints and sanctions for non-compliance, are also relevant. A factor that has a significant bearing on whether a scheme can ensure fair outcomes is whether workers are bonded to a particular employer in circumstances where the threat of expulsion can be used as a tool of coercion and exploitation.

One benchmark against which temporary labour mobility schemes can be measured is the extent to which they adhere to the norms established in

\footnotetext{
33 See, e.g., Federal Court of Australia, Hanssen Pty Ltd v Jones, [2009] FCA 192 (4 March 2009).

World Bank, Pacific Islands at Home and Away, p. 117.

35 United Food and Commercial Workers Canada, National Report: Status of Migrant Farm Workers in Canada (Toronto: UFCW Canada, 2002), p. 21.

36 World Bank, Pacific Islands at Home and Away, p. 137.
} 
international instruments relevant to the treatment of migrant workers. ${ }^{37}$ The International Labour Organization has concluded two treaties dealing specifically with migrant labour, but Australia is not party to either of them. ${ }^{38}$ More recently, the United Nations General Assembly adopted a comprehensive convention on migrant workers, which came into force in 2003, but Australia-keeping company with nearly all net migrant receiving states-is not party to that instrument either. ${ }^{39}$ Australia's failure to ratify these conventions does not mean that it fails to observe the conventions' core principles in practice, yet ratification would no doubt provide a measure of comfort to Pacific Island countries by signalling that their nationals are entitled to an international minimum standard of treatment when working in Australia.

In the absence of guarantees under international law, alternative protections have been put in place to minimize the risk of exploitation of seasonal workers, and it is to these that we now turn. The interrelationships between relevant actors are illustrated in figure 1.

Figure 1

Organizational Relationships between Key Actors

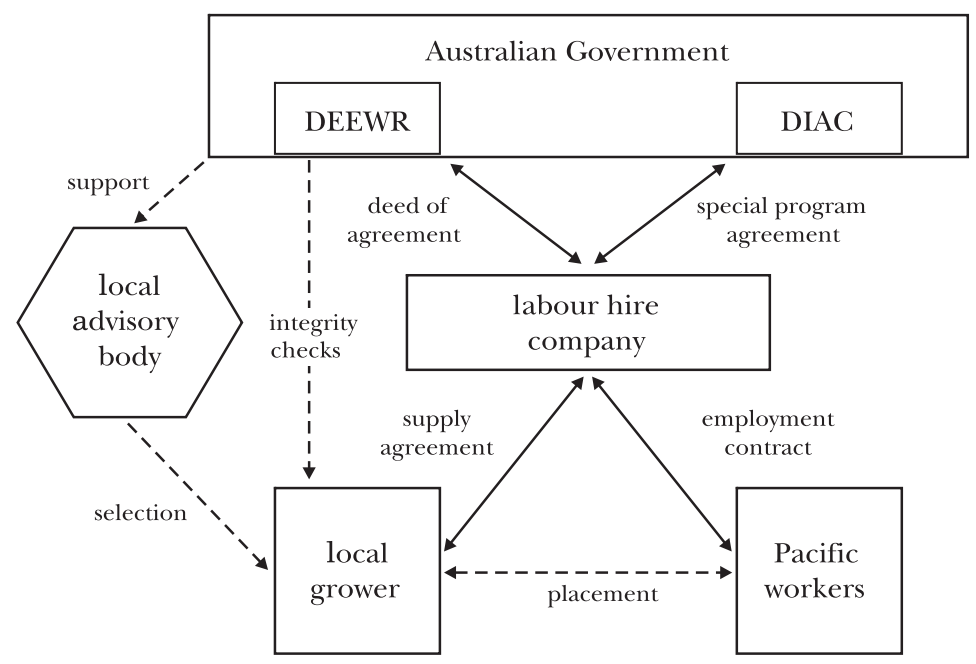

37 R. Cholewinski, "The Rights of Migrant Workers," in R. Cholewinski, R. Perruchoud, and E. MacDonald, ed., International Migration Law: Developing Paradigms and Key Challenges (The Hague: TMC Asser Press, 2007).

38 Convention Concerning Migration for Employment (ILO No. 97), adopted in 1949, and the Convention Concerning Migrations in Abusive Conditions and the Promotion of Equality of Opportunity and Treatment of Migrant Workers (ILO No.143), adopted in 1975.

39 International Convention on the Protection of the Rights of All Migrant Workers and Members of their Families 1990. 


\section{Intergovernmental agreements}

The bilateral agreements that have been entered into between Australia and participating Pacific Island countries are an important source of protective measures for seasonal workers. As noted above, Australia has entered into MOUs with three Pacific Island countries_-Kiribati, Tonga and Vanuatu-and an agreement with Papua New Guinea is still to be signed. The MOUs set out the operational principles governing the scheme, the desired outcomes and critical factors by which the effectiveness of the scheme will be evaluated.

The protection of Pacific workers is recognized under each of these themes. For example, the operational principles include "equity of access and opportunity for workers" and "investing maximum effort to mitigate risk to ... participating nationals." The desired outcomes include "avoiding unethical recruitment practices [or] exploitation of workers." And the critical success factors will gauge the scheme's effectiveness by whether "[Pacific] nationals enjoy...fair and reasonable treatment by approved Australian employers" and whether seasonal workers "are not levied with any recruitment costs or subject to excessive up-front charges". ${ }^{40}$

The worker protections identified in the MOUs are important because they state the common understanding of the parties at the commencement of the scheme, but they suffer from several limitations. They do not cover the broad spectrum of rights and obligations that are found in comprehensive international instruments. They do not create binding legal obligations between states: as instruments of "less than treaty status," they operate only in the moral and political spheres. Moreover, their language is very general, leaving open both the possibility of different interpretations and the necessity of further arrangements to make the principles operational.

The MOUs are supported by detailed "facilitative arrangements" which purportedly deal with issues of recruitment, pre-departure and on-arrival information, the role of trade unions, pastoral support in Australia and access to training. It is likely that these arrangements articulate protections for Pacific workers beyond those stipulated in the MOUs. However, the details of the facilitative arrangements have not been released into the public domain because they are regarded as "private arrangements" ${ }^{41}$ and, presumably, because different concessions have been negotiated with each country.

\section{Departmental oversight}

The pilot scheme is unusual for the high degree of government oversight of what would otherwise be private employment arrangements. Two

40 See, e.g., Australian Government, "Memorandum of Understanding between the Australian Government and the Government of the Republic of Vanuatu in Support of Australia's Pacific Seasonal Worker Pilot Scheme (PSWPS)" (Canberra: Australian Department of Education, Employment and Workplace Relations, 2008).

${ }_{41}$ Personal correspondence with DEEWR, 28 July 2009. 
departments are closely involved in supervising operational aspects of the scheme. The lead department is the Department of Education, Employment and Workplace Relations (DEEWR), which exercises functions in two main areas. In relation to growers, DEEWR receives applications from growers who wish to access Pacific workers; it assesses whether they have made genuine attempts to recruit local Australian labour; and it conducts integrity checks about their immigration, workplace relations and occupational health and safety history. In relation to labour hire companies, DEEWR receives and evaluates expressions of interest from companies that wish to employ Pacific workers, and it scrutinizes each company's financial viability and its history of workplace practices. Successful applicants must enter into a detailed "deed of agreement" with DEEWR, which sets out their obligations under the program, including monitoring and reporting requirements.

The other department involved in the scheme is the Department of Immigration and Citizenship (DIAC), which oversees the issuing of immigration visas. Each selected labour hire company is required to enter into "special program agreement" with DIAC and it is then able to enter into commercial arrangements with growers to host the Pacific workers for all or part of their stay in Australia. The special program agreement sets out the obligations of the labour hire company but these extend far beyond migration-related matters, indeed it forms an integral part of the special regulatory framework for administering the scheme. Among the most important obligations, a labour hire company is required to (a) pay the full upfront cost of each worker's airfares, with the ability to recoup half the cost from the worker over the period of employment; (b) meet all transport costs of the Pacific workers between the arrival and departure point and the location of the work; (c) guarantee Pacific workers a minimum average of 30 hours work per week for six months; (d) provide briefings and appropriate induction and training; (e) provide pastoral care and assist workers with arranging accommodation, health care and banking facilities; and (f) communicate in writing if any financial deductions are to be made for airfares, advances for living expenses or accommodation. Labour hire companies are also required to reimburse the government up to AUD $\$ 10,000$ for any costs incurred by the government in trying to locate and remove a seasonal worker who overstays his or her visa. This institutional incentive to promote visa compliance is supported by the prohibition on seasonal workers bringing dependants to Australia and by the opportunity for circular migration in which visa-compliant workers can obtain work in future harvest seasons. ${ }^{42}$

42 Australian Government, "Factsheet: What Will the Australian Government Do to Prevent Overstaying by Pacific Seasonal Workers?" (Canberra: Department of Education Employment and Workplace Relations, 2009). 


\section{Local advisory bodies}

A third level of regulatory control comes from the establishment of local advisory bodies in each of the geographic regions in which Pacific workers undertake work for growers. These bodies comprise six members-two representatives from local employers in the horticulture industry, one from local government, one from a trade union and two from community organizations, including churches. Each local advisory body is supported by government representatives from DEEWR and DIAC who observe and assist in deliberations. The bodies serve a number of functions. They provide advice to DEEWR on local conditions and on applications by local growers to participate in the scheme. They also consult about the role of labour hire companies in each region and liaise with labour hire companies appointed to manage the recruitment and placement of Pacific seasonal workers in the region. Local advisory bodies can also play a part in facilitating and monitoring pastoral care for workers, but it is clear that labour hire companies will have to take a broader view of their role as employers than may have been typical in the past.

\section{Labour hire arrangements}

The pilot seasonal worker scheme makes it very clear that Pacific workers will be employed only by labour hire companies and not directly by growers. During the first phase of the arrangements, a number of labour hire companies were approved to employ and place a small number of Pacific workers; initially one engaged Tongan workers in the Swan Hill-Robinvale region and another engaged ni-Vanuatu workers in the Griffith region. Additional labour hire companies have now been selected for the second phase of the scheme.

Labour hire arrangements are not new to the Australian labour market, where they have been used to achieve flexibility in a number of industries for many years. ${ }^{43}$ This has also been the case in the horticulture industry, where growers meet their seasonal demand for labour by supplementing their own employees with workers contracted through labour hire companies. What differs about the arrangements under the pilot scheme is that the nature of the employment arrangements is not left to the discretion of growers but is dictated by government as a regulatory condition of participation in the scheme.

The Australian government has suggested a number of reasons for designating labour hire companies rather than growers as the employers. It removes financial risk from growers and simplifies the negotiation of

43 Productivity Commission, The Role of Non-Traditional Work in the Australian Labour Market (Canberra: Australian Government, 2006). 
industrial instruments; it assists government in monitoring wages and conditions and in overseeing the practices of employers; and it facilitates the regulation of employers through codes of conduct applicable to the labour hire industry. The importance of the last point is demonstrated by the criteria that DEEWR uses to select labour hire companies. One criterion is that the applicant "is a member of the Recruitment and Consulting Services Association Ltd (RCSA) or another Australian peak recruitment body or [is] willing to comply with the RCSA Code of Conduct or similar industry standard." Thus the government's regulatory framework for the pilot scheme includes the potential to require compliance with industry self-regulation.

In other contexts, the trilateral work relationships established by the involvement of labour hire companies have been problematic because of the mixed legal relationships between the parties. ${ }^{44}$ In the pilot scheme the labour hire company is clearly designated as the employer and, like most labour hire arrangements, there is no contract of employment between the grower and the worker (see figure 1). This avoids a common problem associated with temporary work schemes, namely, that the worker is tied to a single host and is therefore vulnerable to exploitation under the threat of being sent home. Under the Australian scheme, the tying is not to a single grower but to a single labour hire company. This can also create difficulties where workers have a dispute about their treatment at the hands of the labour hire company or where the company has difficulty maintaining an adequate supply of work. Moreover, there may be problems if workers have a dispute with a grower, since the labour hire company may be reluctant to disrupt its commercial relations with the grower by intervening on the workers' behalf.

\section{General workplace regulation and its application to seasonal workers}

One of the critical failures of Australia's 457 visa scheme was that temporary migrants were exempted from the industrial regulation governing wages and conditions of Australian workers. As discussed above, this left migrant workers exposed to the risk of discrimination and exploitation, and for some migrants this risk became a reality. This design failure has now been remedied and has not been repeated under the seasonal worker pilot scheme. This part considers how the general regulatory framework of Australian industrial law, policy and process applies to seasonal workers and therefore supplements the special arrangements considered above.

How will workplace regulation in Australia respond to the challenges posed by a seasonal worker scheme? The pilot scheme is premised on the assumption that the scheme should not involve any lowering of workplace

44 R. Owens and J. Riley, The Law of Work (Melbourne: Oxford University Press, 2007), pp. 150-154. 
standards or any loss of jobs for Australian workers. Trade unions have historically opposed such schemes on the basis that they are "exploitative of the guest and exploitative of unemployed Australians." ${ }^{45}$ Although there has been a softening of opposition to a seasonal worker scheme by some sectors of the trade union movement, their principal concerns of not undermining jobs and wages remain.

\section{Recent reforms}

The last decade has seen a fundamental realignment of Australia's collective framework of workplace relations to a very different model of labour regulation. Australia's traditional model of industrial relations relied heavily on centralized bargaining and arbitrated awards but from the early 1990s successive Australian governments-both liberal and conservative-began to allow for greater flexibility and enterprise-level bargaining. The changes introduced by the conservative Howard government in 2005 by the Work Choices legislation represented the high water mark of efforts to achieve a decentralized industrial relations system. ${ }^{46}$ These reforms "all but completely dismantled the traditional Australian labour law system" ${ }^{47}$ and put in place a new regime characterized by a very limited safety net, little scope for arbitration, an emphasis on individual rather than collective agreements, weakened enforcement mechanisms and marginalization of collective values. $^{48}$

Australian workplace regulation is now at another critical juncture, with a different Australian government seeking to redress what it perceives as the imbalance of reforms instituted since the early 1990s, under a policy called Forward with Fairness. ${ }^{49}$ The first piece of legislation to implement this policy took effect in March 2008. ${ }^{50}$ It brought to an end the use of statutory individual agreements and set up an ongoing process of award modernization. The next phase of the reform agenda, the Fair Work Act (2009), claims to rebalance Australian workplace relations towards fairer outcomes. ${ }^{51}$ Most of the new legislative scheme came into force on 1 July 2009, although aspects of the scheme such as award modernization were postponed until 1 January 2010.

45 Australian Workers' Union, Inquiry into Pacific Regional Seasonal Contract Labour: Submission to Senate Employment, Workplace Relations and Education References Committee (Melbourne: AWU, 2006), p. 4.

46 Workplace Relations Amendment (Work Choices) Act 2005 (Cth).

47 Owens and Riley, The Law of Work, p. 78.

48 J. Riley and P. Sheldon, eds., Remaking Australian Industrial Relations (Sydney: CCH Australia Ltd, 2008), pp. xix-xx, 5, 21-24, 35-36.

49 Australian Labor Party, ALP National Platform and Constitution 2007 (Canberra: ALP National Conference, 2007).

50 Workplace Relations Amendment (Transition to Forward with Fairness) Act 2008 (Cth).

51 A. Stewart, “A Question of Balance: Labor's New Vision for Workplace Regulation,” Australian Journal of Labour Law, vol. 22 (2009), pp.3-50. 
These changes form the backdrop against which the seasonal worker scheme will be assessed. Although some Pacific workers arrived in Australia during the final days of the previous workplace relations regime, the vast majority will work under the new regime. The new industrial relations climate has the potential to provide Pacific workers with a more favourable working environment than previous regimes. The new parameters of workplace regulation are likely to restore a greater collective focus to workplace regulation and to offer more safeguards through the incorporation of a broader industrial safety net. The expanded safety net, in the form of National Employment Standards together with the reduced capacity to rely on statutory individual contracts, are likely to offer greater protections to vulnerable employees.

\section{Awards and agreements}

Horticulture and agriculture have been described as precarious industries involving low union coverage, limited government regulation and a highly casualized, mobile workforce. ${ }^{52}$ These factors present particular challenges in providing industrial protection for workers. The terms and conditions for workers in this industry are governed by a complex regulatory framework comprised of a number of sources. First, there are awards negotiated for particular industries. A modernized award-the Horticulture Award 2010-has been prepared for the horticulture industry and commenced operation in 2010. Second, the new National Employment Standards set out minimum legislative entitlements on matters such as working hours and leave. Third, some employers have contractual arrangements with their workers to pay above the award rates to reflect market conditions. And finally, some employers negotiate a collective agreement applicable to their workforce alone but these are not widespread.

Early briefings by the Australian government indicated that one of the responsibilities of labour hire companies would be to negotiate an appropriate industrial instrument to cover the terms and conditions of seasonal workers. The Australian Workers Union (AWU), which covers many workers in this industry, put forward a framework agreement outlining the terms and conditions of employment under the scheme, including matters such as deductions and remittances. At this stage, it is unknown to what extent individual labour hire companies will base their arrangements on the framework agreement.

The application of different industrial instruments to the work undertaken by Pacific seasonal workers can be illustrated by the example of the 50 Tongan workers who arrived in Australia in February 2009. They were initially engaged

\footnotetext{
52 N. Maclellan, "Seasonal Workers for Australia: Lessons from New Zealand," Farm Policy Journal,
} vol. 5, no. 3 (2008), pp. 47-48. 
to pick almonds in the Robinvale region in Victoria and were employed by a labour hire company called Tree Minders. There was conflict from the start between the labour hire company and the relevant trade union, the AWU. Tree Minders chose not use the AWU's framework agreement—relying instead on minimum entitlements in the horticulture award-and it employed the workers as casuals rather than as permanent employees for the duration of their stay in Australia. These arrangements put in jeopardy a fundamental aspect of the scheme, namely, that the workers would be guaranteed 30 hours work per week for six months. The difficulties came to a head with the collapse of the company (Timbercorp) that owned the farms on which the work was being done. This left the labour hire company without adequate work for the Tongan workers.

Ultimately, the Tongan workers were re-employed by a different labour hire company and were split into two groups for the remainder of their visa period. Some workers were relocated to Queensland to work on the citrus harvest. A smaller group remained in Victoria pruning table grapes. The AWU became involved in negotiations on behalf of the workers, who were then employed under terms and conditions consistent with the framework agreement. The six ni-Vanuatu workers employed in the Griffith region were employed under the framework agreement from the outset, and their status was that of permanent employees.

The difficulties experienced so early in Australia's pilot scheme highlight some of the challenges of using labour hire companies as intermediaries. Under their special program agreement with DIAC, labour hire companies undertake to provide each worker with an average of at least 30 hours work per week for six months, although the demand for seasonal labour is ultimately within the control not of labour hire companies but of growers. In New Zealand these difficulties have been largely avoided by direct employment arrangements between Pacific workers and growers.

\section{Occupational health and safety}

A fundamental obligation of an employer, both under statute and the common law, is to provide a safe and healthy place of work for its employees and contractors. The employer is responsible for ensuring the safety of the worksite, the work systems in place, and the storage and handling of potentially harmful materials. This obligation requires employers to undertake hazard identification and risk assessments to ensure all steps are taken to prevent and control risks to the health and safety of their workers. This extends to providing adequate information, instruction, training and supervision of workers, as well as consulting with workers about occupational health and safety (OHS) issues. For Pacific seasonal workers, these core obligations are replicated under the terms of the special program agreement.

Obligations under Australian OHS laws attach not only to an employment relationship but to entities engaged in labour hire arrangements, including 
the labour hire company that employs the labour and the host to whom the services of the worker are provided. Thus, both the grower and the labour hire company must proactively manage risks to the health and safety of Pacific workers who are engaged at the work site and ensure that appropriate actions are taken to avoid risks to health and safety.$^{53}$ Growers have an obligation to ensure all reasonable steps are taken to prevent workers being exposed to risks to their health or safety while working at a grower's site. ${ }^{54}$ Additionally, labour hire companies, as employers, have an obligation to assess the workplace for risks before placing the workers, to examine the growers' OHS policies and procedures, to make their workers aware of OHS procedures and hazards at the site and to provide on-site training. ${ }^{55}$

Effective communication is a key factor in controlling risks to health and safety. The ILO has noted that "language and cultural barriers require specific OHS communication, instruction and training approaches. ${ }^{556}$ Pacific seasonal workers are likely to be unfamiliar with many of the practices used in Australian horticulture, to be inexperienced in the use of chemicals employed in intensive farming and to have different (and probably lower) expectations about health and safety standards. It may be questioned whether many of the workers have sufficient knowledge of safety standards, at least on their first placing, to enable them to resist working in conditions that may be judged unsafe. Although proficiency in English is a desired attribute for participating in the scheme, for many Pacific workers English is a second or third language and may not be at a level sufficient to understand instructions, read signage or labelling and communicate effectively in the workplace to avoid health and safety risks.

It is also foreseeable that many seasonal workers will be keen to work long hours to maximize the financial return from their temporary stay, even when they may have an injury or are susceptible to a repetitive use injury. The extent to which adequate medical screening is done before departure will have an impact in this area. In Victoria there is a statutory obligation to provide information in an appropriate language, and an OHS Compliance Code provides guidance on these issues. ${ }^{57}$ Vigilance in supervision will also play a part in ensuring the heath and safety of seasonal workers, as will the role of trade unions in ensuring compliance with health and safety standards.

53 R. Johnstone and M. Quinlan, "The OHS Regulatory Challenges Posed by Agency Workers: Evidence from Australia,” Employee Relations, vol. 28, no. 3 (2006), pp. 273-289.

54 Occupational Health and Safety Act 2004 (Vic) ss 23-24; Occupational Health and Safety Act 2000 (NSW) ss 8(2), 9(1).

55 Johnstone and Quinlan, "OHS Regulatory Challenges," p. 282.

56 International Labour Organization, Towards a Fair Deal for Migrant Workers in the Global Economy. Geneva: International Labour Office, 2004, para.153.

57 Occupational Health and Safety Act 2004 (Vic) s 22(1)(c); Worksafe Victoria, Compliance Code: Communicating Occupational Health and Safety across Languages (Melbourne: Worksafe Victoria, 2008). 


\section{Exploitation and discrimination}

The potential for exploitation of seasonal workers has been one of the principal objections to such schemes for some time. The lack of social and cultural support networks for temporary workers, the absence of long-term job security and the prospect of being sent home arbitrarily all operate to place temporary workers in a vulnerable position. In minimizing the risk of exploitation and discrimination, Australia has the capacity to learn vital lessons from its experience with 457 visas under the temporary skilled migration program discussed above.

Both labour hire companies as employers, and growers as hosts, have a statutory obligation to ensure all reasonable steps are taken to prevent and eliminate discrimination and harassment in the workplace. How should these obligations be realized in practice? This requires a proactive approach to minimize the risk of discrimination and harassment in advance of placing workers. The required preparatory work extends to providing workers with information on workplace rights during pre-departure and on-arrival processes. It also extends to ensuring that equal employment opportunity policies and procedures are in place at the workplace, that existing work practices are non-discriminatory in their application to Pacific workers and that growers receive training to create a non-discriminatory environment. Ultimately, the knowledge that seasonal workers have about avenues for redress and the access they have to effective dispute resolution processes will have a significant impact on the potential for exploitation and discrimination.

\section{Trade union involvement}

We have already noted that trade unions in Australia historically have been "absolutely opposed to guest labour schemes." ${ }_{58}$ This position has now shifted, with some Australian unions accepting that a temporary labour scheme can be of mutual benefit to primary industries and to neighbouring Pacific states, provided it does not involve any lowering of employment standards and conditions. Part of this shift may be attributed to the fact that labour shortages in these industries forced growers to rely increasingly on an undocumented workforce comprising a mixture of overseas students working beyond their visas, individuals working while in receipt of Australian social security benefits and those with no visa entitlement to work. ${ }^{59}$ There is no guarantee that labour supplied through these channels will enjoy terms and conditions of employment that comport with existing labour standards, and it was thus in

58 Australian Council of Trade Unions, ACTU's Submission to the Senate Employment, Workplace Relations and Education Committee Enquiry into Pacific Region Seasonal Contract Labour (Melbourne: ACTU, 2006).

59 Australian Workers' Union, Submission to Senate Inquiry, pp. 7-8. 
the interests of trade unions to ensure that labour shortages were met through more formal and regulated channels.

Trade unions have an interest in ensuring that the wages and conditions of Pacific workers meet the minimum standards set in the relevant industrial instruments. The ability of trade unions to access workplaces to speak to workers about their working conditions will be important to the proper oversight of the seasonal worker scheme. Rights of entry have been a contentious aspect of previous workplace reform agendas. ${ }^{60}$ The changes introduced by the Fair Work Act 2009 allow for more liberal rights of entry, and a change of some significance in the context of seasonal workers is that trade unions will have access to a workplace for the purpose of discussions even if they currently have no members there. Trade unions also have specific rights of entry to investigate alleged breaches of OHS laws.

\section{Resolving disputes and monitoring compliance}

Seasonal worker schemes need robust processes for dealing with workplace disputes, particularly if Pacific workers feel vulnerable to being sent home if they make complaints or if cultural differences in the articulation and settlement of grievances make them reticent about voicing their concerns through formal channels. ${ }^{61}$ Concerned about these issues, some Pacific communities have chosen their initial participants for their good communication skills so that they may speak on behalf of other workers and help to resolve any difficulties.

There are established procedures for dealing with disputes that arise in relation to employment issues. All awards and collective agreements must contain a dispute settlement clause, and they must make provision for the use of informal procedures to resolve grievances about entitlements. ${ }^{62}$ Where disputes arise regarding provisions in an award or agreement, or with respect to other work conditions, seasonal workers may use these dispute resolution processes directly or a trade union may act on their behalf.

As with any regulatory scheme, effective compliance and enforcement relies on the willingness of informed individuals to come forward with grievances. Because many Pacific workers lack knowledge of Australian workplace practices, it is incumbent on government agencies to be proactive in seeking out seasonal workers to ascertain whether the scheme is functioning well in practice. Workplace inspectors have the power to enter workplaces to ascertain if rights and obligations under laws, agreements, awards or orders

\footnotetext{
60 I. Ross and J. Trew, Bargaining under Work Choices (Sydney: Butterworths, 2006), ch.8.

61 G. Hassall, "Alternative Dispute Resolution in Pacific Island Countries," Journal of South Pacific Law, vol. 9, no. 2 (2005) available online at http://www.paclii.org/journals/fJSPL.

62 J. Riley and T. Sarina, "The New Conflict Managers: A Critical Assessment of Alternative Dispute Resolution Methods under Workchoices," in G. Michelson, S. Jamieson and J. Burgess, ed., New Employment Actors: Developments from Australia (Bern: Peter Lang, 2008).
} 
are being complied with. Inspectors have the power to initiate legal action to restrain certain conduct, impose penalties or recover outstanding monies. They also play a part in ensuring freedom of association and in facilitating a trade union's right of entry to a workplace. It is vital that the powers of the inspectorate are harnessed within the seasonal worker scheme to facilitate compliance and enforcement. Similarly, local advisory boards will have significant responsibilities of oversight of the scheme in particular localities, and can thus facilitate local compliance with regulatory processes and support dispute resolution mechanisms.

\section{Beyond a pilot scheme?}

The Australian seasonal worker scheme has been implemented as a pilot program and is scheduled to be reviewed to gauge its effectiveness in contributing to development goals, meeting labour shortages in particular industries, and addressing strategic priorities for the region. So far, there appear to have been genuine tri-partite efforts to ensure the pilot scheme becomes fully operational, but whether this can be sustained in the long term remains to be seen. This small pilot scheme has been estimated to cost the government alone AUD $\$ 23.6$ million (including establishment, monitoring and evaluation) ${ }^{63}$ which is two-thirds of the estimated total wages bill of all 2,500 Pacific workers. It is an open question whether Australiaonce described as a "reluctant Pacific nation" ${ }^{4}$ — will move beyond the pilot to a more permanent arrangement for facilitating labour migration in the Pacific. As Australia's minister for foreign affairs has observed, the government has been pleased with the trial to date but has "a fair way to go before coming to a final judgement about whether [it] could take that forward in any permanent way into the future". ${ }^{65}$

The scheme was purposely introduced as a pilot—involving a small number of workers over a finite period-so that appropriate evaluation could be undertaken before implementing a more enduring program. Yet, even by the modest standards set, very low numbers of Pacific workers have been deployed in the Australian horticulture industry compared with the New Zealand scheme. The absence of Pacific workers from the start of the second successive harvest season in December 2009 has raised concerns about the viability of the scheme.

63 Australian Senate, Economic Challenges Facing Papua New Guinea and the Island States of the Southwest Pacific (Canberra: Foreign Affairs, Defence and Trade References Committee, 2009), p. 204.

64 G. Dobell, "The Reluctant Pacific Nation: Policy Taboos, Popular Amnesia and Political Failure," Quadrant, vol. 47, no. 5 (2003), pp.16-23.

65 Stephen Smith MP, "Press Conference: The Hon Stephen Smith MP and Tongan Prime Minister Dr the Hon Feleti Sevele, Minister for Foreign Affairs" (Nuku'alofa: Department of Foreign Affairs, 3 June 2009). 
In some respects the timing of Australia's initiative has not been propitious. The domestic and regional goals of the scheme have to be delivered in the face of competition from a New Zealand program that started earlier, operates on a significantly larger scale and builds on stronger ties with countries of the Pacific and with Pacific Island communities who have residents within New Zealand. In addition, the global financial crisis has contributed to a gloomier labour market outlook than was the case when the pilot scheme was first announced. A soft domestic labour market may mean there are fewer labour shortages that need to be filled using non-Australian labour. However, in the long term neither of these factors is likely to have a sustained impact on the viability of the Australian scheme. New Zealand is a small economy whose seasonal labour needs cannot meet the demand for employment by Pacific Island peoples. Moreover, the Australian economy has fared well in the global financial crisis by international standards ${ }^{66}$ and on balance it seems likely that there will continue to be labour shortages in the regional locations that the scheme is designed to serve and in the type of low skilled, low paid work to which the scheme is directed.

An evaluation of the pilot has been set up to examine whether the scheme is meeting its twin objectives of achieving development goals and increasing domestic labour supply. Much of the rhetoric surrounding the scheme has advocated a regulatory framework that is fair, efficient and effective. This article has examined this regulatory environment from two perspectives: the arrangements that have been put in place specifically to address the seasonal migration of Pacific workers and the application of mainstream industrial regulations to those who arrive under the scheme. As noted earlier, these protections are a political necessity from the viewpoint of the government's relations with Pacific neighbours, trade unions and the Australian public. They are also part of Australia's general legal obligations to safeguard the rights of individuals who are present in its territory, including foreign workers. The regulatory framework outlined in this article indicates that a very high priority for the Australian government is to avoid any suggestion of, or opportunity for, exploitation of Pacific workers. This objective necessitates a high level of oversight and engagement by government departments, industry associations and labour organizations. An important consideration in evaluating the pilot is whether the type and level of regulation is sustainable if the scheme were to expand in size and duration.

As one of the objectives of the scheme is to meet local labour shortages, it is also important to consider the viability of the scheme from an industry perspective. The horticulture industry has traditionally been subject to limited regulation and has relied on a highly casualized and transient

66 Reserve Bank of Australia, Statement on Monetary Policy, 7 August 2009 (Canberra: Reserve Bank of Australia, 2009). 
workforce. Industry sources are already saying that "red tape," "delays," "onerous government conditions" and "excessive micro-management [by government]" have made Pacific workers unattractive to growers. ${ }^{67}$ It has also been suggested that growers are reluctant to shoulder the financial premium required to cover the travel and administration costs of bringing seasonal workers from the Pacific and that the mandatory use of labour hire companies as intermediaries has pushed up labour costs from $\$ 18$ to over $\$ 22$ per hour. ${ }^{68}$ These factors have the potential to drive growers back to their traditional sources of seasonal labour, including dubious contractors and undocumented workers. Ironically, it may be the very web of regulation that has been woven around the scheme to protect Pacific workers that may make their employment less attractive to growers.

There will always be a concern that temporary labour schemes create possibilities for exploiting vulnerable workers, especially if the demand for short-term labour is met by the movement of people across the "North-South" divide. Australia's history, both recent and distant, is a palpable reminder of these risks. If Australia's seasonal labour scheme is to bear fruit in the future, it is vital that it is nurtured today through a strong regulatory framework that is vigilantly monitored and enforced to avoid the slightest suggestion that they are the new "blackbirders." To date, the pilot has been painstaking in its efforts to ensure the integrity of its protective framework, but opportunities for Pacific workers have been quite limited in practice. The forthcoming evaluation of the pilot will have to meet the challenge facing all temporary migration schemes, namely, how to enable foreign workers to exploit new employment opportunities without themselves being exploited. Hopefully this elusive goal does not lie beyond the reach of the scheme.

Macquarie University, Sydney, Australia, January 2010

67 T. Hyland, "Islander Work Scheme Bears No Fruit," The Age (online), 22 November 2009, available online at http:/ / www.theage.com.au/national/islander-work-scheme-bears-no-fruit-20091121is7z.html, last accessed 24 March 2010.

68 Hyland, "Islander Work Scheme Bears No Fruit." 


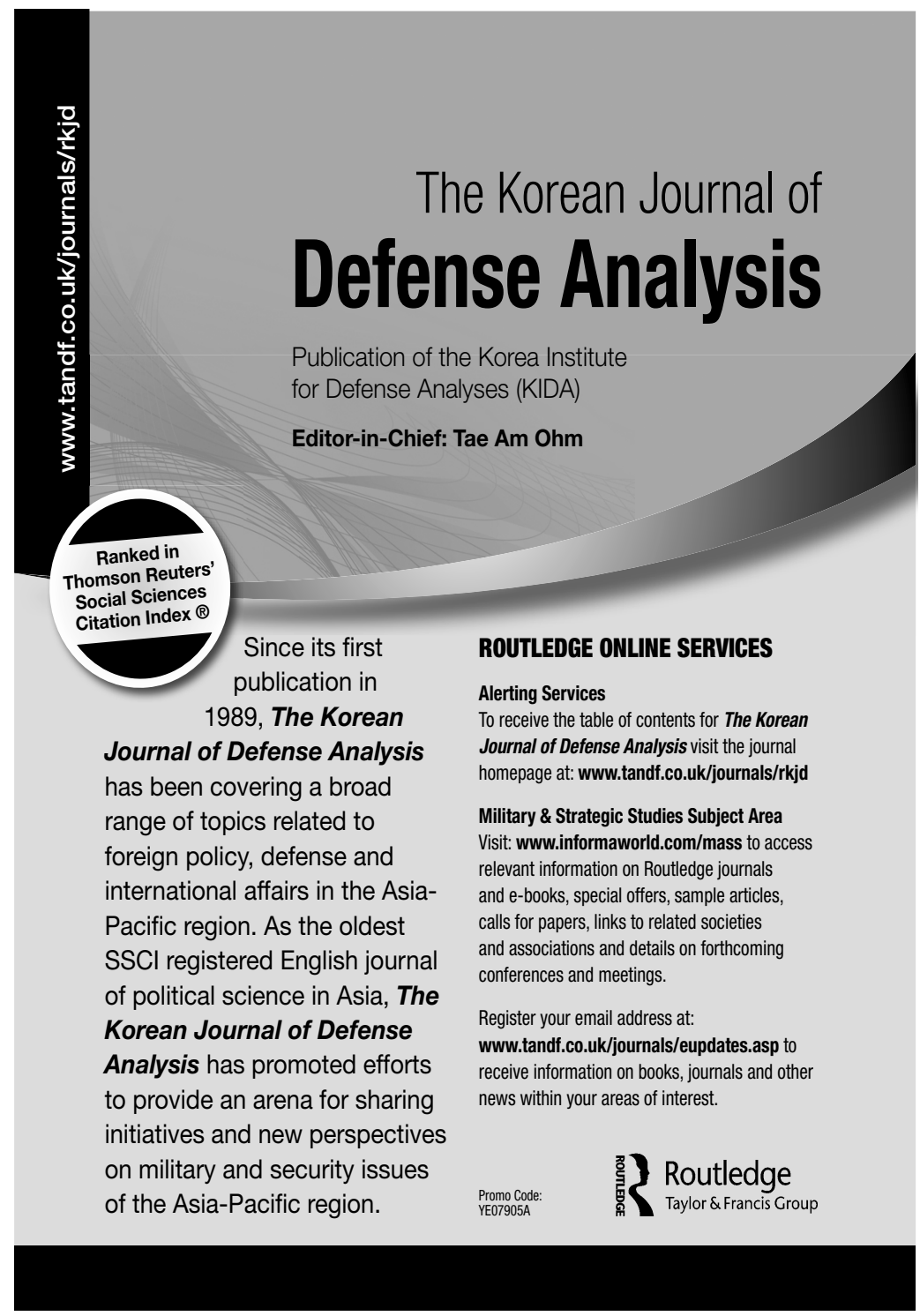

